\title{
PENGARUH PENGGUNAAN MODEL PEMBELAJARAN KOOPERATIF TIPE TEAM ASSISTED INDIVIDUALIZATION (TAI) BERBANTU PETA KONSEP TERHADAP HASIL BELAJAR IPS TERPADU
}

Eva Kurniasih'1, Dra. Hj. Ningrum. M.TA2 ${ }^{2}$ Tiara Anggia Dewi, M.Pd. ${ }^{3}$

Program Studi Pendidikan Ekonomi, Universitas Muhammadiyah Metro

Email: kurniasiheva943@gmail.com 1, ningrummta@gmail.com 2, tiara.anggia.d@gmail.com ${ }^{3}$

\begin{tabular}{lr}
\hline KATA KUNCI & \\
\hline & \\
Model & Pembelajaran \\
Kooperatif & Tipe Team \\
Assisted & Individualization \\
(TAI), Peta & Konsep, Hasil \\
Belajar &
\end{tabular}

Belajar

\section{ABSTRAK}

Hasil belajar IPS Terpadu peserta didik kelas VII SMP Negeri 2 Punggur tahun pelajaran 2019/2020 masih banyak yang belum tuntas atau dibawah ketuntasan minimum (KKM) yaitu 6,66. Disebabkan karna banyak faktor yang mempengaruhinya seperti metode ceramah diskusi tanya jawab. Sehingga peserta didik cenderung bosan dan pasif dikarenakan pembelajarannya kurang berkesan dan menarik. Model pembelajaran kooperatif tipe team assisted individualization (TAI) berbantu peta konsep merupakan salah satu model pembelajaran yang inovatif. Penggunaan model kooperatif tipe team assisted individualization (TAI) berbantu peta konsep tepat untuk kegiatan pembelajaran dikelas untuk mendapatkan partisipasi peserta didik secara keseluruhan, menuntut peserta didik untuk lebih aktif, berfikir kritis dan bertanggung jawab.

Teknik pengumpulan data menggunakan metode wawancara, dokumentasi dan test. Untuk menguji hipotesis menggunakan analisis Regresi Linier Sederhana diperoleh $\mathrm{Y}^{\mathrm{I}}=40,2669+0,5350$. Hasil $t_{\text {hitung }}=4,08$ dan $t_{\text {tabel }}=1,697$ dengan taraf signifikan $5 \%$. Hipotesis dapat dihitung sebab $t_{\text {hitung }}>t_{\text {tabel }}$ yaitu 4,08 $>1,697$. Dengan demikian menunjukan bahwa model pembelajaran kooperatif tipe team assisted individualization (TAI) berbantu peta konsep mempunyai pengaruh yang positif terhadap hasil belajar IPS Terpadu peserta didik kelas VII SMP Negeri 2 punggur tahun pelajaran 2019/2020.

\section{KEYWORDS}

Cooperative Learning Model Integrated Social Studies learning outcomes for grade VII students of Type Team Assisted SMP Negeri 2 Punggur 2019/2020 school year there are still many Individualization (TAI), unfinished or below the minimum completeness (KKM) which is 6.66. Concept Maps, Learning Because there are many factors that influence it, such as the question Outcomes and answer discussion method. So students tend to be bored and passive because the learning is less memorable and interesting. The team assisted individualization (TAI) type of cooperative learning model assisted with concept maps is one of the innovative learning models. The use of cooperative assisted individualization (TAI) type 
models assisted with concept maps appropriate for classroom learning activities to get overall student participation, requiring students to be more active, think critically and responsibly.

Data collection techniques using interview, documentation and test methods. To test the hypothesis using Simple Linear Regression analysis obtained $Y I=40.2669+0.5350$. Tcount $=4.08$ and table $=$ 1.697 with a significant level of 5\%. Hypothesis can be calculated because tcount> ttable is 4.08> 1.697. Thus it shows that the cooperative learning model of the type of team assisted individualization (TAI) assisted with concept maps has a positive influence on the results of Integrated Social Studies learning for grade VII students of SMP Negeri 2 punggur in the academic year 2019/2020.

\section{PENDAHULUAN}

Pendidikan merupakan suatu hal yang harus dipenuhi dalam upaya meningkatkan taraf hidup bangsa Indonesia agar tidak sampai tertinggal dengan bangsa lain. Kualitas pendidikan merupakan salah satu faktor yang menentukan kualitas sumber daya manusia (SDM) suatu bangsa. Begitu juga sebaliknya, SDM merupakan salah satu faktor yang menentukan kualitas pendidikan. Melalui pendidikan, diharapkan mampu mewujudkan peningkatan kualitas Sumber Daya Manusia demi mendukung kelangsungan pembangunan nasional, khususnya dalam menghadapi era persaingan global.

Keberhasilan pendidikan tercermin dalam proses belajar dan hasil belajar. Dengan demikian untuk meraih hasil belajar yang optimal, dibutuhkan relasi dari seluruh komponen pendidikan meliputi peserta didik, guru, kurikulum dan sarana penunjang pendidikan. Peserta didik merupakan komponen utama dibanding yang lain, sebab peserta didik merupakan sasaran utama yang akan dibimbing untuk menjadi manusia berkualitas, tangguh dalam menghadapi era globalisasi. Selain itu peserta didk merupakan tolok ukur keberhasilan pendidikan itu sendiri.

Guru menciptakan kondisi dan situasi yang memungkinkan peserta didik membentuk makna dari bahan-bahan pelajaran melalui suatu proses pembelajaran dan menyimpannya dalam ingatan yang sewaktu-waktu dapat diproses dan dikembangkan lebih lanjut. Seorang guru dapat menumbuhkan rasa ingin tahu siswa salah satunya dengan menggunakan bahan ajar yang menarik dan kreatif.

Berdasarkan hasil pra survey dan wawancara yang dilakukan peneliti di SMP Negeri 2 Punggur kelas VII, hasil belajar peserta didik pada mata pelajaran IPS terpadu masih ada beberapa kelas yang tingkat ketuntasannya kurang yaitu pada kelas VII A dan kelas VII C . Hal ini disebabkan karena kurangnya bahan ajar yang digunakan pada saat kegiatan pembelajaran. Data tersebut terlihat pada table berikut:

Table 1. Data Hasil Belajar Ulangan Harian Peserta Didik Kelas VII SMP Negeri 2 Punggur

\begin{tabular}{ccccclcc}
\hline & & & & & \multicolumn{2}{c}{$\begin{array}{c}\text { Jumlah } \\
\text { Keseluruhan }\end{array}$} \\
\cline { 6 - 8 } No & Kelas & $\begin{array}{c}\text { Ketunta } \\
\text { san } \\
\text { Belajar }\end{array}$ & $\begin{array}{c}\text { Kategori } \\
\text { Ketuntasan } \\
\text { Belajar }\end{array}$ & $\begin{array}{c}\text { Jumlah } \\
\text { Peserta } \\
\text { Didik }\end{array}$ & $\begin{array}{l}\text { Persentas } \\
\text { e (\%) }\end{array}$ & $\begin{array}{c}\text { Peserta } \\
\text { Didik }\end{array}$ & $\begin{array}{c}\text { Perseta } \\
\text { se (\%) }\end{array}$ \\
\hline 1 & VII A & $\geq 6,66$ & Tuntas & 10 & 31.25 & & 100 \\
& $<6,66$ & Belum & 22 & 68.75 & 32 & \\
& & Tuntas & & & &
\end{tabular}


Vol. 2, No. 1, November 2021

\begin{tabular}{|c|c|c|c|c|c|c|c|}
\hline \multirow[t]{2}{*}{2} & \multirow[t]{2}{*}{ VII B } & $\geq 6,66$ & Tuntas & 19 & 59.38 & \multirow[t]{2}{*}{32} & \multirow[t]{2}{*}{100} \\
\hline & & $<6,66$ & $\begin{array}{l}\text { Belum } \\
\text { Tuntas }\end{array}$ & 13 & 40.62 & & \\
\hline \multirow[t]{2}{*}{3} & \multirow[t]{2}{*}{ VII C } & $\geq 6,66$ & Tuntas & 8 & 25.80 & \multirow[t]{2}{*}{31} & \multirow[t]{2}{*}{100} \\
\hline & & $<6,66$ & $\begin{array}{l}\text { Belum } \\
\text { tuntas }\end{array}$ & 23 & 74.20 & & \\
\hline \multirow[t]{2}{*}{4} & \multirow[t]{2}{*}{ VII D } & $\geq 6,66$ & Tuntas & 18 & 64.29 & \multirow[t]{2}{*}{28} & \multirow[t]{2}{*}{100} \\
\hline & & $<6,66$ & $\begin{array}{l}\text { Belum } \\
\text { tuntas }\end{array}$ & 10 & 35.71 & & \\
\hline
\end{tabular}

Sumber: Hasil Pra Survey Nilai Ulangan Harian Semester Genap Peserta Didik Kelas VII SMP Negeri 2 Punggur Tahun Pelajaran 2019/2020

Berdasarkan hasil pra survei yang dilakukan, diperoleh informasi berupa hasil ulangan harian semester genap tahun pelajaran 2019/2020. Pada hasil tersebut masih banyak peserta didik yang belum memenuhi kriteria ketuntasan minimum (KKM sebesar 6,66. Pada kelas VIIA dengan jumlah peserta didik 32, peserta didik yang mencapai ketuntasan hanya 10 peserta didik atau dengan persentase $31,25 \%$ sedangkan yang tidak mengalami ketuntasan sebanyak 22 peserta didik dengan persentase $68,75 \%$. Pada kelas VIIB dengan jumlah peserta didik 32, peserta didik yang mencapai ketuntasan hanya 19 peserta didik atau dengan persentase 59,38\% sedangkan yang tidak mencapai ketuntasan sebanyak 13 peserta didik atau dengan persentase $40,68 \%$. Pada kelas VIIC jumlah peserta didik 31, peserta didik yang mencapai ketuntasan hanya 8 peserta didik atau dengan persentase $25,80 \%$ sedangkan yang tidak mencapai ketuntasan sebanyak 23 peserta didik atau dengan persentase 74,30\%. Pada kelas VIID dengan jumlah peserta didik 28, peserta didik yang mencapai ketuntasan hanya 18 peserta didik atau dengan persentase $64,29 \%$ sedangkan yang tidak mencapai ketuntasan sebanyak 10 peserta didik atau dengan persentase 35,71\%. Maka berdasarkan hasil pra survey tersebut dapat diambil kesimpulan bahwa pada kelas VIIA sebagai kelas eksperimen dan kelas VIIC sebagai kelas kontrol karena pada kelas tersebut masih banyak peserta didik yang belum mengalami ketuntasan pada hasil belajar IPS Terpadu.

Berdasarkan permasalahan tersebut peneliti memberikan alternatif model kooperatif tipe team assisted individualization (TAI) berbantu peta konsep untuk mengatasinya, karena model ini menekankan kerjasama tim dengan cara yang tuntas akan dipilih sebagai ketua kelompok untung mengajari teman-temannya. Langkah pertama tes penempatan,peserta didik diberi tes awal untuk mengetahui kemampuan awal peserta didik. Kemudian guru membentuk kelompok menjadi beberapa kelompok berdasarkan hasil tes awal yang telah ditentukan setelah itu guru memberikan lembar kerja atau modul kepada setiap kelompok kemudian peserta didik yang mempunyai kemampuan yang lebih tinggi diharapkan dapat membantu peserta didik yang kurang paham. Kemudian guru memberikan pelajaran secara individual kepada peserta didk yang membutuhkan, selanjutnya tahap akhir guru memberikan penilaian dan penghargaan kelompok kepada kelompok yang memiliki nilai tertinggi berdasarkan lembar kerja yang telah dilakukan. Model pembelajaran ini diharapkan dapat digunakan untuk meningkatkan aktivitas belajar dan meningkatkan ketuntasan belajar peserta didik khususnya mata pelajaran IPS Terpadu.

Model kooperatif tipe team assisted individualization (TAI) berbantu peta konsep merupakan salah satu model pembelajaran yang inovatif. Penggunaan model kooperatif tipe team assisted individualization (TAI) berbantu peta konsep dipilih karena tepat untuk kegiatan pembelajaran dikelas untuk mendapatkan partisipasi peserta didik secara keseluruhan, menuntut peserta didik untuk lebih aktif, berfikir kritis dan bertanggung jawab. Diharapkan hasil belajar peserta didik dapat meningkat atau mencapai KKM (kriteria ketuntasan 
minimum) setelah dilakukan pembelajaran dengan menggunakan model kooperatif tipe team assisted individualization (TAI) berbantu peta konsep.

Berdasarkan latar belakang yang telah di paparkan, maka penulis mengangkat judul sebagai berikut: "PENGARUH PENGGUNAAN MODEL PEMBELAJARAN KOOPERATIF TIPE TEAM ASSISTED INDIVIDUALIZATION (TAI) BERBANTU PETA KONSEP TERHADAP HASIL BELAJAR IPS TERPADU PESERTA DIDIK KELAS VII SMP NEGERI 2 PUNGGUR TAHUN PELAJARAN 2019/2020"

Berdasarkan rumusan masalah diatas yang menjadi tujuan penelitian adalah "Untuk mengetahui pengaruh penggunaan Model Pembelajaran Kooperatif Tipe Team Assisted Individualization (TAI) Berbantu Peta Konsep Terhadap Hasil Belajar IPS

Terpadu Peserta Didik Kelas VII SMP Negeri 2 Punggur Tahun Pelajaran 2019/2020" Model pembelajaran merupakan rencana yang akan digunakan guru dikelas. Ada beberapa pengertian model pembelajaran menurut para ahli. Menurut Joyce \& Weil (Rusman, 2010:132) menyatakan bahwa Model pembelajaran adalah suatu rencana atau pola yang dapat digunakan untuk membentuk kurikulum (rencana pembelajaran jangka panjang), merancang bahan-bahan pembelajaran, dan membimbing pembelajaran dikelas atau yang lain. Model pembelajaran sangat dibutuhkan dalam proses pembelajaran agar kegiatan pembelajaran memiliki tujuan dan lebih menarik, salah satu model yang dapat digunakan adalah model kooperatif, dengan model kooperatif peserta didik dilatih untuk bekerja sama dengan temannya. Menurut Slavin (Etin, 2012:102)mengatakan bahwa Cooperative learning adalah suatu model pembelajaran di mana belajar dan bekerja dalam kelompok-kelompok kecil secara kolaboratif yang anggotanya terdiri dari 4 sampai 6 orang, dengan struktur kelompoknya yang bersifat heterogen

Pembelajaran kooperatif tipe team assisted individualization (TAI) merupakan salah satu pembelajaran yang menitik beratkan pada proses belajar kelompok. Menurut Robert Slavin (Huda, 2018:200) merupakan sebuah program pedagogik yang berusaha mengadaptasikan pembelajaran dengan perbedaan individual siswa secara akademik.

Kegiatan belajar mengajar hendaknya harus bersifat kreatif dan memunculkan ide-ide dan menggunakan cara-cara yang menarik, salah satu nya menggunakan peta konsep. Menurut Ariffuddin (Urmila,dkk, 2019:313) menyatakan

Peta konsep merupakan diagram yang menunjukkan hubungan antara konsep-konsep yang mewakili pembelajaran, dari materi yang umum akan diletakan di paling atas kemudian diikuti oleh sub-sub materi yang khusus. Peta konsep merupakan gambaran konkret dari suatu materi yang disajikan dalam bentuk semacam diagram. Peta konsep ini berfungsi sebagai pemandu peserta didik dalam mengingat inti-inti dari pembelajaran sehingga peserta didik mudah mengingat inti dari materi pembelajaran. Sutirman (2013: 36-37) langkahlangkah team assisted individualization (TAI) sebagai berikut:

a. Tes penempatan, pada awal pembelajaran siswa diberikan tes awal untuk mengetahui kemampuan awal siswa. Hasil tes tersebut akan dijadikan dasar dalam pembentukan kelompok.

b. Membentuk kelompok, guru membagi siswa menjadi beberapa kelompok berdasarkan hasil tes awal yang telah dilakukan.

c. Memberikan bahan ajar, guru memberikan lembar kerja atau modul kepada siswa.

d. Belajar dalam kelompok, siswa membaca materi pelajaran dan mengarjakan soal-soal latihan secara individu. Siswa yang memiliki kemampuan lebih tinggi diharapkan dapat membantu memberi penjelasan kepada siswa yang kurang paham, sehingga dapat mengerjakan dengan benar.

e. Guru memberikan pelajaran secara individual kepada siswa yang membutuhkan. 
Penilaian dan penghargaan kelompok, kelompok yang memiliki nila tertinggi berdasarkan lembar kerja yang telah dilakukan, diberikan sebuah penghargaan.

\section{Metode Penelitian}

Sifat penelitian yang akan dilakukan adalah pengaruh, yang mengkaji pengaruh variable bebas terhadap variable terikat. Penelitian ini mencari bagaimana pengaruh model pembelajaran kooperatif tipe team assisted individualization (TAI) berbantu peta konsep terhadap hasil belajar IPS terpadu. Penelitian ini menggunakan Quasi exsperimental design dengan bentuk nonequivalent control group design. Dalam desain ini terdapat dua kelas eksperimen dan kelas kontrol yang tidak dipilih secara random. Dua kelompok yang ada akan diberi pretest kemudian diberi perlakuan dan yang terakhir diberi posttest unutuk membandingkan kedua kelas tersebut. Menurut sugiyono (2013:116) jika Desain penelitian yang digunakan adalah

Non-Equivalen Group Design maka menggunakan perlakuan sebagai berikut:

\begin{tabular}{|lll|}
\hline $\mathrm{O}_{1}$ & $\mathrm{X}$ & $\mathrm{O}_{2}$ \\
\hline $\mathrm{O}_{3}$ & & $\mathrm{O}_{4}$ \\
\hline
\end{tabular}

Pada $\mathrm{O}_{1}$ merupakan kelas eksperimen dan $\mathrm{O}_{3}$ merupakan kelas kontrol.

\section{Tahapan}

Proses pembelajaran dalam penelitian ini dilaksanakan dengan tatap muka sebanyak $4 \mathrm{x}$ baik pada kelas eksperimen maupun kelas kontrol, dengan perincian waktu $1 \mathrm{x}$ untuk pre-test, 2x pertemuan untuk menyampaikan materi dengan menerapkan model kooperatif tipe team assisted individualization (TAI) berbantu peta konsep serta tahap evaluasi post-test $1 \mathrm{x}$ pertemuan. Rancangan penelitian dalam penelitian ini adalah:

a. Tahap persiapan atau perencanaan penelitian

1) Menetapkan sampel kelas eksperimen dan kontrol.

2) Mempelajari kurikulum pembelajaran IPS terpadu dan buku ajar untuk mempersiapkan bahan ajar serta membuat rencana pelaksanaan pembelajaran (RPP).

3) Menyusun soal-soal evaluasi uji coba.

b. Tahap pelaksanaan perlakuan (treatment) penelitian

1) Peserta didik dibentuk kelompok team assisted individualization (TAI).

2) Peserta didik diberi soal yang berbentuk peta konsep tentang permintaan, penawaran, harga dan pasar.

3) Peserta didik berdiskusi mengenai soal yang berbentuk peta konsep yang berisi materi permintaan, penawaran, harga dan pasar.

4) Guru memberi bimbingan kepada kelompok yang belum memahami materi.

5) Kelompok yang pertama selesai dengan hasil jawaban yang tepat diberi skor tertinggi.

6) Pemberian reward atau kartu penghargaan kepada kelompok dengan skor tertinggi.

c. Tahap akhir penelitian

1) Menganalisis data hasil pengujian dari pre-test dan post-test.

2) Membandingkan hasil pengujian dari tes awal (pre-test) dan tes akhir (post- test). Menyimpulkan hasil penelitian.

\section{HASIL PENELITIAN}

Hipotesis yang dinilai dalam penelitian ini adalah hipotesis nol $\left(\mathrm{H}_{0}\right)$ yaitu terdapat perbedaan yang signifikan hasil belajar IPS Terpadu peserta didik yang dibelajarkan melalui model pembelajaran kooperatif tipe team assisted individualization (TAI) berbantu peta konsep dengan hasil belajar IPS Terpadu yang dibelajarkan melalui pembelajaran konvensional pada kelas VII SMP 
Negeri 2 Punggur Kecamatan Punggur. Berdasarkan hasil post-test kelompok eksperimen yang menggunakan model pembelajaran kooperatif tipe team assisted individualization (TAI) berbantu peta konsep memperoleh nilai mean dari data adalah 62,75 dan nilai simpangan bakunya adalah 10,0486 Kriteria uji, tolak $\mathrm{H}_{0}$ jika $x^{2}{ }_{h i t} \geq x^{2}(1-q)(k-3)$ dan dalam hal lainnya $\mathrm{H}_{0}$ diterima, berdasarkan tabel dapat diketahui bahwa banyaknya kelas interval adalah 6 , maka $x^{2}$ daf adalah 6-3 =3 dengan menggunakan taraf nyata $(\alpha)=0,05$ harga $x^{2}$ daf dapat dilihat pada daftar H (Lampiran). Taraf nyata $5 \%$ atau 0,05 diperoleh 7,81 Ternyata untuk taraf nyata 0,05 didapat bahwa $X^{2}{ }_{h i t}<X^{2}{ }_{d a f}$. Untuk taraf nyata 0,05 adalah: 5,33<7,81 yaitu 2,48. Berdasarkan kriteria uji diatas maka dapat disimpulkan bahwa $\mathrm{H}_{0}$ diterima.Hal ini menunjukan bahwa distribusi frekuensi nilai pre-test peserta didik kelas eksperimen mengikuti distribusi normal.

Berdasarkan pendeskripsian data hasil pre-test penelitian bahwasannya nilai mean dari data adalah 73,5 dan nilai simpangan bakunya adalah 12,8514 untuk taraf nyata 0,05 didapat bahwa $X^{2}{ }_{h i t}<X^{2}{ }_{d a f}$. Untuk taraf nyata 0,05 adalah: $3.97<7,81$ yaitu3.84 . Berdasarkan kriteria uji diatas maka dapat disimpulkan bahwa $\mathrm{H}_{0}$ diterima.Hal ini menunjukan bahwa distribusi frekuensi nilai post-test peserta didik kelas eksperimen mengikuti distribusi normal.

Hasil Uji Homogenitas Kriteria uji tolak $\mathrm{H}_{0}$ jika $F_{h i t} \geq F_{\text {daf }}$ dan terima $\mathrm{H}_{0}$ untuk $F_{\text {hit }}$ lainnya, berdasarkan tabel diketahui bahwa banyaknya sampel adalah 32 maka $F_{d a f}$ adalah 32-1 =31. Dengan menggunakan taraf nyata $(\alpha)=10 \%$ atau 0,1 dapat dilihat pada daftar I (lampiran).

Untuk taraf nyata $(\alpha)=10 \%$ atau 0,1 diperoleh 2,38 Perhitungan tersebut dapat dilihat bahwa baik untuk taraf nyata $(\alpha)=10 \%$ ternyata $F_{\text {hit }}<F_{\text {daf }}$ untuk kriteria $10 \%$ adalah: $0,06<2,38$ yaitu 2,32. Berdasarkan kriteria uji diatas, maka dapat disimpulkan bahwa $\mathrm{H}_{0}$ diterima. Hal ini menunjukan bahwa kedua sampel berasal dari populasi yang memiliki varians yang sama atau kedua populasi dalam keadaan homogen. Kedua kelompok sampel yang diambil diketahui berasal dari populasi yang berdistribusi normal dan homogen, maka dilanjutkan dengan pengujian hipotesis. Setelah data yang diperoleh uji hipotesis dilakukan dengan Maka data dianalisis terlebih dahulu menggunakan rumus regresi linier sederhana. Analisis untuk mengetahui hubungan dua variabel Setelah diketahui $t_{\text {hitung }}$ maka langkah selanjutnya adalah membandingkan dengan $t$-tab. Jika $\mathrm{t}_{\text {-hitung }}>\mathrm{t}$-tab berarti hipotesisnya diterima.Apabila $\mathrm{t}_{\text {-hitung }}<\mathrm{t}$-tab berarti hipotesisinya ditolak. Dengan demikian hipotesisnya berbunyi: Ada pengaruh yang positif penggunaan model pembelajaran kooperatif tipe team assisted individualization (TAI) terhadap hasil belajar IPS Terpadu peserta didik kelas VII SMP Negeri 2 Punggur tahun pelajaran 2019/2020, maka hipotesisnya diterima. Untuk taraf nyata 5\% atau 0,5 diperoleh 1.697 dilihat pada daftar tabel G (lampiran) Analisis perhitungan nilai $t_{\text {hitung }}$ dan $t_{\text {tabel }}$ tersebut berarti diketahui bahwa $t_{\text {hitung }}>t_{\text {tabel }}$ dapat dilihat pada daftar G, pada taraf signifikan 5\% yaitu $4.08>1.697$. Dengan demikian, maka hipotesisnya diterima yang berarti bahwa: Ada pengaruh yang positif penggunaan modelpembelajaran kooperatif tipe team assisted individualization (TAI) terhadap hasil belajar IPS Terpadu peserta didik kelas VII SMP Negeri 2 Punggur tahun pelajaran 2019/2020. Berdasarkan nilai-nilai dari hasil belajar IPS Terpadu peserta didik dari evaluasi uji pretest dan posttest, setelah diberikan treatment menggunakan pembelajaran model pembelajaran kooperatif tipe team assisted individualization (TAI) pada kelas VII.A .Dapat diketahui bahwa pada tahap evaluasi uji pretest bahwa peserta didik yang mencapai tuntas belajarnya hanya 37,5\% (12 peserta didik), sedangkan peserta didik yang belum mencapai tuntas belajar adalah $62,5 \%$ (20 peserta didik). setelah peserta didik mendapatkan treatment atau perlakuan menggunakan model pembelajaran kooperatif tipe team assisted individualization (TAI) yang mencapai tuntas belajar berjumlah 24 peserta didik dengan presentase $7,68 \%$, sedangkan peserta didik yang belum mencapai tuntas belajar berjumlah 8 peserta didik dengan presentase 2,56\%, dari total keseluruhan peserta didik sebanyak 32 peserta didik.

Dalam penelitian ini setelah peserta didik mendapatkan treatment atau perlakuan menggunakan model pembelajaran kooperatif tipe team assisted individualization (TAI) terhadap hasil belajar IPS Terpadu mengalami peningkatan dilihat dari perbandingan pada evaluasi pretest 
dan evaluasi posttest, yaitu peserta didik yang mencapai kriteria ketuntasan minimal pada evaluasi pretest adalah $37,5 \%$ atau 12 peserta didik dari total keseluruhan peserta didik sebanyak 32 peserta didik, sedangkan peserta didik yang mencapai kriteria ketuntasan minimal pada evaluasi posttest adalah $7,68 \%$ atau 24 peserta didik, dari total keseluruhan peserta didik sebanyak 32 peserta didik.

Berdasarkan hasil analisis penelitian diatas, ada pengaruh positif penggunaan model pembelajaran kooperatif tipe team assisted individualization(TAI) terhadap hasil belajar IPS Terpadu peserta didik kelas VII SMP Negeri 2 Punggur tahun pelajaran 2019/2020.

\section{KESIMPULAN DAN SARAN}

\section{SIMPULAN}

Berdasarkan analisis data maka dapat disimpulkan bahwa : Ada pengaruh yang positif penggunaan model pembelajaran kooperatif tipe team assisted individualization (TAI) berbantu Peta Konsep terhadap hasil belajar IPS Terpadu peserta didik kelas VII SMP Negeri 2 Punggur. Simpulan tersebut ditunjukkan pada temuan hasil analisis sebagai berikut:

a. Hasil penelitian dari 32 peserta didik yang diberikan perlakuan (treatmen) model pembelajaran kooperatif tipe team assisted individualization (TAI) berbantu Peta Konsep,terhadap peserta didik yang hasil belajar IPS Terpadu termasuk dalam kategori tuntas sebanyak 24 peserta didik atau sebesar 7,68\%, sedangkan peserta didik yang hasil belajar IPS Terpadu termasuk dalam kategori belum tuntas sebanyak 8 peserta didik atau sebesar 2,56\%.

b. Pada pengujian rumus Regresi Linier Sederhana diperoleh $40,2669, b=0,5350$ sehingga dengan demikian $Y^{\mathrm{i}}=\mathrm{a}+\mathrm{bX}$, adalah $=40,2669+0,5350$. Kemudian dari hasil analisis yang dilakukan maka terbukti bahwa ada pengaruh yang positif penggunaan Model Pembelajaran Kooperatif Tipe Team Assisted Individualization (TAI) berbantu Peta Konsep terhadap hasil belajar IPS Terpadu peserta didik kelas VII SMP Negeri 2 Punggur. Hal ini dibuktikan dengan penghitungan analisis data dapat diketahui bahwa nilai tersebut $\mathrm{t}$ hitung $>$ t-tab, dan terlihat bahwa pada taraf signifikan 5\% yaitu 4,08 $>1,697$ selisihnya adalah 2,383, yang dapat dilihat pada daftar G tabel statistik. Dengan demikian hipotesis diterima.

\section{SARAN}

1. Bagi Peserta Didik

Peserta didik diharapkan setelah menggunakan model pembelajaran kooperatif tipe team assisted individualization (TAI) berbantu peta konsep ini dapat menumbuhkan motivasi belajar serta mandiri, dan melatih untuk berpikir kritis sehingga pembelajaran yang dilakukan akan lebih bermakna.

2. Bagi Guru

Bagi Guru diharapkan sebagai bahan masukan bagi guru untuk memilih model pembelajaran yang tepat dalam pembelajaran IPS Terpadu. Salah satunya dengan menggunakan model pembelajaran kooperatif tipe Team Assisted Individualization (TAI) berbantu Peta Konsep.

3. Bagi Sekolah

Diharapkan setelah penelitian ini dapat memberikan fasilitas atau sarana dan prasarana yang mendukung peserta didik lebih bersemangat dan nyaman ketika proses pembelajaran berlangsung.

\section{DAFTAR PUSTAKA}


Arikunto, Suharsimi. 2013. Dasar-Dasar Evaluasi Pendidikan. Jakarta: Bumi Aksara Huda, Miftahul. 2018. Model Model Pengajaran Dan Pembelajaran. Yogyakarta : Pustaka Pelajar Urmila Ni Komang Dewi, Ketut Pudjawan, I Nyoman Laba Jayanta. 2019. Pengaruh Model Pembelajaran TAI Berbantuan Media Peta Konsep Terhadap Kompetensi Pengetahuan IPS Siswa Kelas IV Sekolah Dasar. E-Journal PGSD Universitas Pendidikan Ganesha Mimbar PGSD Vol: 5 No: 2 Tahun: 2017.313.

Etin,Solihatin. 2012.Strategi Pembelajaran PPKN. Jakarta: PT Bumi Aksara

Sugiyono. 2013. Metode Penelitian Pendidikan. Bandung: Alfabeta

Sutirman. 2013. Media Dan Model Model Pembelajaran Inovatif. Yogyakarta: Graha Ilmu 